DOI: 10.2478/linpo-2013-0011

\title{
EMPTY CATEGORIES IN THE HINDI-URDU binaa PARTICIPLE CLAUSE
}

\author{
ALICE DAVISON
}

\begin{abstract}
Alice Davison. Empty Categories in the Hindi-Urdu binaa Participle Clause. Lingua Posnaniensis, vol. LV (2)/2013. The Poznan Society for the Advancement of the Arts and Sciences. PL ISSN 0079-4740, ISBN 978-83-7654-274-4, pp. 25-39.
\end{abstract}

Hindi-Urdu has an oblique participle construction meaning 'without', which resembles a parasitic gap construction in other languages. These other languages, like English, have obligatory movement to the left which is a condition on a parasitic gap, as in wh- question sentences. But in Hindi-Urdu, questions do not require leftward movement, allowing the question word to stay in situ. In addition, this participle is possible with statements as well, suggesting that Hindi-Urdu does not have parasitic gaps or obligatory A' movement. This paper explores the actual nature of this participle, concluding that it has a PRO subject and null pronoun object.

KEY WORDS: Hindi-Urdu, empty categories, null pronouns, parasitic gaps, participle clauses, A', wh movement, questions and statements, PRO subjects

Alice Davison, University of Iowa, alice-davison@uiowa.edu

\section{INTRODUCTION}

This paper considers a construction in Hindi-Urdu which consists of the preposition binaa followed by an oblique verbal participle, as in $(1 \mathrm{a}, \mathrm{b})$. The participle clause is notable for lacking an overt subject as well as an overt object. These null arguments are coindexed with the subject and object of the main clause.

$$
\begin{aligned}
& \text { kaun-sii kitaab pheeNk dii [ [binaa } \boldsymbol{e}_{i} \boldsymbol{e}_{j} \text { paRh-ee]? } \\
& \text { which book threw away.PF without read-PF.OBL } \\
& \text { 'Which book } \mathrm{j}_{\mathrm{j}} \text { did you throw away } \mathbf{e}_{\mathbf{j}} \text { [without } \mathrm{PRO}_{\mathrm{i}} \text { reading } \mathbf{e}_{\mathbf{j}} \text { ]?' }
\end{aligned}
$$

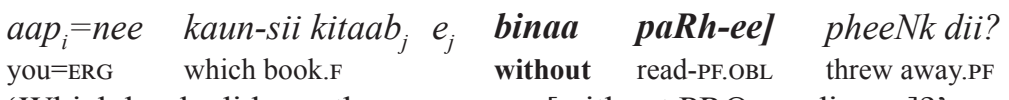

'Which book ${ }_{\mathrm{j}}$ did you throw away $\mathbf{e}_{\mathbf{j}}$ [without $\mathrm{PRO}_{\mathrm{i}}$ reading $\mathbf{e}_{\mathbf{j}}$ ]?'

In the binaa phrase, there are two null arguments, a subject and an object. Analogy to the structure of the English translation would suggest that the first empty category is a controlled PRO subject, while the object is a wh- variable bound by a null operator in the COMP 
position of the participial clause, in other words, a parasitic gap (ENGDAHL 1983; CHOMSKY 1986), as in (2a):

$$
\begin{aligned}
& \text { ? What book did you throw away without }\left[\mathrm{OP}_{\mathrm{i}}\left[\mathrm{PRO}_{\mathrm{j}} \mathbf{e}_{\mathrm{i}} / * \text { it }_{\mathrm{i}} \text { reading }\right]\right. \text { ? } \\
& I_{\mathrm{j}} \text { threw away this book } k_{i}\left[\text { without } \mathrm{PRO}_{\mathrm{j}} \text { reading } \text { it }_{\mathrm{i}} / * \mathrm{e}_{\mathrm{i}}\right] \text {. } \\
& \text { without }\left[\mathrm{OP}_{\mathrm{i}}\left[\mathrm{PRO}_{\mathrm{j}} \mathrm{e}_{\mathrm{i}} \text { reading }\right]\right.
\end{aligned}
$$

A parasitic gap in languages like English and Swedish is well-formed only if syntactic A' movement has taken place, though there are varied judgements among speakers, discussed in ENGDAHL (1983). Where a parasitic gap is possible, an overt pronoun is ungrammatical (2a), but by contrast the pronoun is required where the gap is ungrammatical ( $2 \mathrm{~b}$ ). Parasitic gaps are so strongly associated with movement to the periphery of the clause (A' movement) that they are considered diagnostic for A' movement. Recent work such as MANETTA 2010 has proposed that Hindi-Urdu, normally considered a wh-in situ language, actually has overt A' movement, developing the ideas in MAHAJAN 1990.

In this paper, I ask two questions: (i) Is the null object in the binaa participle an example of a parasitic gap, and (ii) if not, what are the conditions on this participle construction? These questions are of interest because linguistic theory is largely concerned with the licensing of the overt contents of a sentence: what morphological form is consistent with a particular grammatical function, the relative order and hierarchical relations of constituents, and coindexing relations between a dependent constituent and an antecedent elsewhere within a sentence or in discourse. A dependent expression may also be implied, having no phonological form, and it is often the case that a null constituent is more strongly constrained than an overt one, in where it may appear, and where its antecedent may be (eg. HuANG 1984; RIzzi 1990). For this reason, an explanation of how certain types of null constituents are licensed may reveal properties of the grammar of the language in question. Most importantly, these questions bear on the existence of A' movement in Hindi-Urdu in questions. If there are freely occurring parasitic gaps, then it is possible that Hindi-Urdu has A' movement. If there are other explanations for gaps, then the case for A' movement licensing parasitic gaps has little support.

\subsection{THE binaa PHRASE AND PARASITIC GAPS}

In the binaa phrase, there are two null arguments, a subject and an object. Analogy to the structure of the English translation would suggest that the first empty category is a controlled PRO subject, while the object is a wh- variable bound by a null operator in the COMP position of the participial clause, in other words, a parasitic gap (ENGDAHL 1983; CHOMSKY 1986), as in (2c) above.

The null operator forms a chain with the wh- variable, subject to locality conditions, and with its A' binder in the matrix clause. In the absence of an A' chain, the gap is ill-formed (2c). See NunEs 2004 for a more recent proposal for the derivation of parasitic gaps.

Parasitic gaps are licensed by several types of A' movement, including S-structure whmovement, scrambling (WEBELHUTH 1989, 1992) and heavy NP shift. If this analysis were to be carried over to Hindi/Urdu (MAHAJAN 1990), the underlying assumption is that Hindi/ Urdu has the same repertory of null categories as English (historically a distantly related 
language), and the same licensing conditions. But Hindi/Urdu is a language which does not require overt wh- movement to the left periphery of the clause, and it also allows for null pronominals (pro) under much less stringent conditions than English. For these reasons, this assumption is in question.

\subsection{THE IDENTIFICATION OF NULL CATEGORIES}

Within the general Chomskyan paradigm, there are different kinds of null constituents, each with different identifying properties (CHOMSKY 1981, 1982, 1995). The properties have to do with the results of movement (3a) and (3b) or the absence of movement, the presence of abstract case marking, and an independent thematic role (3c) and (3d). The possibilities are summed up in (3):

NP trace (Result of A-movement to subject position, such as passive, thetamarked but without structural Case.)

We(nominative) were invited

Wh- trace (Result of movement to the specifier of the complementizer phrase at the left periphery of the clause, as in question and relative clause movement. The original position is marked with case. ${ }^{1}$ )

Whom did you invite ?

(3c) PRO (Independent theta role, null case, and an antecedent in the main clause.) We(i) want $[\mathrm{PRO}($ null case)(i) to invite them.

(3d) pro (Independent theta role, occurs in a position where case is marked; limited in English.)

pro is a null pronominal, often identified by discourse.

Take two eggs . Beat $_{\mathrm{i}}$ pro $_{\mathrm{i}}$ thoroughly.

In addition to the four main types of empty category, there is another kind of gap which is called parasitic, as it seems to depend on another gap of the type (4a), the result of obligatory and overt movement to the periphery of the clause. ${ }^{2}$

Parasitic gap (Like a wh- variable, licensed by S-structure A' movement)

Null operator, in A' position, binding the parasitic gap.

? Which book did $_{i}$ you $_{j}$ throw away __ [ without $\mathrm{OP}_{\mathrm{i}} \mathrm{PRO}_{\mathrm{j}}$ reading _ _i $\left.{ }^{*}{ }^{*} i t_{\mathrm{i}}\right]^{3}$ ?

1 In English, other kinds of movement license parasitic gaps, such as Heavy NP Shift to the right:

(i) I threw away _ $\left[\right.$ [without PRO reading __ $[\text { [a huge number of out of date files }]_{\mathrm{i}}$

2 Anoop Mahajan remarked at the conference presentation of this paper that the question version of the sentence is odd if there is an overt pronoun rather than an empty object. While this point deserves further investigation, the explanation may be independent of the issue of parasitic gaps. The overt pronoun yah ' $3 \mathrm{sg}$ this' and woo '3sg that' have some semantic content in addition to being pronouns, while the null pro is devoid of person and number features. It also does not express reference proximal to or distal from the speaker or reference point, as the overt deomonstrative pronouns do. The overt pronouns, however, more easily take on a bound variable interpretation from quantified antecedents than the null pronominal, assuming that the quantified object antecedent does c-command a CP adjoined to VP, and containing the pronoun.

3 For many English speakers, parasitic gap sentences are not fully grammatical, though they can be frequently found in natural discourse, written and spoken. 
The essential properties of the parasitic gap sentences are the following:

(i) There is a wh-phrase/operator which is moved overtly to the left periphery leaving a gap.

(ii) There is a subordinate clause with a null category coindexed with the wh- gap; an overt pronoun is ungrammatical.

(iii) The PRO subject of the subordinate infinitive clause is coindexed with an antecedent in the main clause. ${ }^{4}$

The principal question asked in this paper is whether Hindi-Urdu has parasitic gaps of the type shown in (1a, b), licensed in the same way as English and Swedish, etc. I will propose that it does not, and that the null object is an example of the null pronominal pro. I will also show that the null subject in the bina a participle is a controlled PRO, with an antecedent in the main clause. I will point out special properties of the null categories which serve to identify the specific type of empty category.

\section{PARASITIC GAPS}

If the sentences in (1) have exactly the same derivation as the English translation, then two predictions should be correct: (a) the null object should be ill-formed in the corresponding sentence WITHOUT a questioned phrase and (b) an overt pronoun should not be possible. The first prediction is not met in (5), which is a declarative sentence with a well-formed binaa clause and a null object:

$$
\begin{aligned}
& \text { maiN }_{i}=\text { nee } \quad \text { yah kitaab }_{j} \text { pheeNk dii } \quad \text { [binaa } e_{i} e_{j} \text { paRh-ee] } \\
& \text { '(* in English) I threw away this book } \mathrm{j}_{\mathrm{j}} \text { [without } \mathrm{PRO}_{\mathrm{i}} \text { reading } \mathrm{e}_{\mathrm{j}} \text {.' }
\end{aligned}
$$

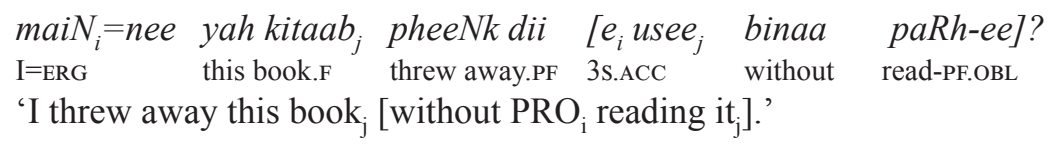

The same sentence also allows an overt pronoun object. This result should not be unexpected, if Hindi/Urdu is basically a wh- in-situ language. If there is A' movement, it takes place in deriving Logical Form. Yet as ENGDAHL (1983) and others point out, overt A' movement is essential for licensing parasitic gaps in languages which have them. A-movement and LF A' movement are equally unsuitable licenses for parasitic gaps.

\section{THE binaa CONSTRUCTION}

Declarative sentences like the ones in (5) and (6) are normal in Hindi/Urdu, consisting of a perfective verb participle in the oblique, which gives the embedded clause an adverbial

4 Other kinds of finite subordinate clauses are possible, which are not relevant to the present discussion of the binaa participle. 
role. For example, the binaa sentence in (7a) is not far in meaning from the negative participle in $(7 b)$ :

$$
\begin{aligned}
& \text { maiN us aadmii } i_{i}=\text { see [binaa PRO } e_{j} \text { pasand kiy-ee] mil-aa } \\
& \text { I-NOM that man=with without liking do-PF.OBL meet-PF } \\
& \text { 'I met this man }{ }_{j} \text { [without PRO liking } \mathrm{e}_{\mathrm{j}} \text { ].' } \\
& \begin{array}{lllllll}
\text { maiN } & \text { [pro } & \text { us aadmii=koo } & \text { na pasand } & \text { kar-tee } & \text { huee } & \text { bhii] }_{\text {pro }} \\
\text { I:NOM } & \text { that man=ACC } & \text { not liking } & \text { do-IMPF } & \text { be-PF } & \text { also }
\end{array} \\
& \text { mil-aa } \\
& \text { meet-PF } \\
& \text { 'I met this man not liking him.' }
\end{aligned}
$$

The binaa clause is not very different from other oblique participle clauses, except that the position of binaa and of the whole binaa clause is somewhat variable. The whole clause may be within the matrix clause, at the end $(1 \mathrm{a}, \mathrm{b})$, or preposed $(8)$ :

$\left[\mathrm{PRO}_{\mathrm{i}} \begin{array}{l}\text { film deekh-ee binaa }] \text { bhii, un } \\ \text { film see-PF } \\ \text { without even } 3 \mathrm{PL}=\mathrm{PAT}\end{array}\right.$
$\begin{aligned} & \text { bahut pataa hai } \\ & \text { much information is }\end{aligned}$

'Even without $\mathrm{PRO}_{\mathrm{i}}$ seeing the film, they $\mathrm{i}_{\mathrm{i}}$ have a lot of information about it.'

Within the embedded clause, the head binaa may precede the object and verb (1)-(2), separate the object and verb (9), or follow the verb (8):

$$
\begin{aligned}
& \text { maiN }_{i}=\text { nee yah kitaab }{ }_{j} \text { pheeNk dii [usee } \text { binaa }_{i} \text { paRh-ee]? } \\
& \text { I=ERG this book.F threw away-PF it.ACC without read-PF.OBL }
\end{aligned}
$$

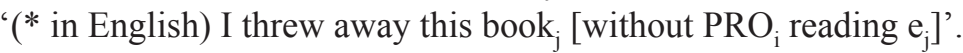

While I will not attempt to account for all these variations here, it is clear that binaa and an oblique perfective participle form a closely connected phrase, allowing different ordering within it, and this unit, like other non-finite clauses, clearly projects a subject position and an object position, though they may be null.

Returning to the question of whether the null object position is a parasitic gap, we may compare the analysis of English parasitic gaps in CHOMSKY (1986) with what would have to be said for Hindi-Urdu. The parasitic gap is the 'end' of a complex chain which consists of the gap, its A' antecedent, a null operator or pro in Spec of CP, and the chain formed by A' movement of a non-null operator. Hence the null operator must move to Spec/CP to derive the locality violations which occur in the parasitic domain. This movement is plausible for English, which does allow wh- movement within infinitives (10a):

(10a) We are thinking about [what to do].

(10b) *We are thinking about [what (our) doing].

$\begin{array}{llll}\text { ham }[\mathrm{PRO} \text { kyaa } \quad k a r-n e e]=k i i \text { sooc } & \text { rahee } & \text { haiN*(?) } \\ \text { we what do-inf=GEN think } & \text { PROG } & \text { be.PL } \\ \text { 'What are we thinking of [PRO doing e]?' } & & \\ \text { Not 'We are thinking of [what PRO to do e].' } & & \end{array}$


The Hindi/Urdu infinitive in (10c) does not allow the translation (10a), with embedded wh- scope. In this and all other kinds of non-finite clauses, wh- scope is always in the matrix finite clauses, never local within an emebedded clause. (Note, however, that English gerunds also fail to have local wh- scope (10b), even though parasitic gap clauses would have null operators in the same position as the ungrammatical what in (10b).) The analysis of Hindi/Urdu using a null operator in an embedded non-finite CP loses plausibility given that non-finite clauses typically fail to have (interrogative) operators in a local A' relation.

\section{CONTROL OF PRO}

It is relatively uncontroversial that the null subject of binaa clauses is PRO. If there is a control relation, then the subject position is obligatorily coindexed with a matrix syntactic anatecedent, and no overt subject, especially a different subject, is possible. This property is demonstrated with embedded infinitive sentence in $(11 \mathrm{a}, \mathrm{b})$ :

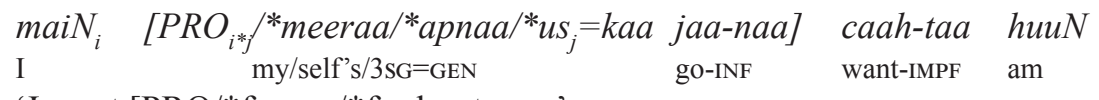

$$
\begin{aligned}
& \text { 'I want }[\mathrm{PRO} / * \text { for } \mathrm{me} / * \text { for her to go.' }
\end{aligned}
$$

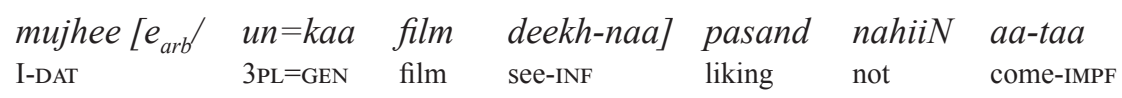

'I don't like [(their) seeing the film].'

PRO is controlled in (11a), allowing no overt subject. The structure of (11b) is somewhat different, as the embedded infinitive could be regarded as the subject of a small clause whose predicate is pasand 'liking'. Here the subject is not controlled, and may be disjoint from the matrix subject.

We see in (12) versus (13) that the binaa construction does not allow even coindexed overt subjects (12) but requires PRO (13):

$\begin{array}{lllll}{ }^{*}{ }^{*} \text { un }=\text { kee }_{i} & \text { film } & \text { deekhee } & \text { binaa }]=\text { bhii, un } \\ \text { 3PL }=\text { GEN } & \text { film } & \text { see-PF } & \text { without=even } & \text { 3PL=DAT }=k e e \\ \text { baaree-meeN } & \text { bahut } & \text { pataa } & \text { hai } \\ \text { about } & \text { much } & \text { information } & \text { is }\end{array}$
'Even without their ${ }_{i}$ seeing the film, they ${ }_{i}$ have a lot of information about it.'

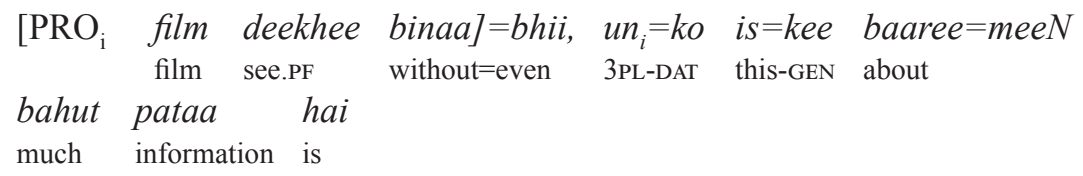

'Even without $\mathrm{PRO}_{\mathrm{i}}$ seeing the film, they have a lot of information about it.'

A sentence which is similar in meaning allows coreference of overt subjects (14):

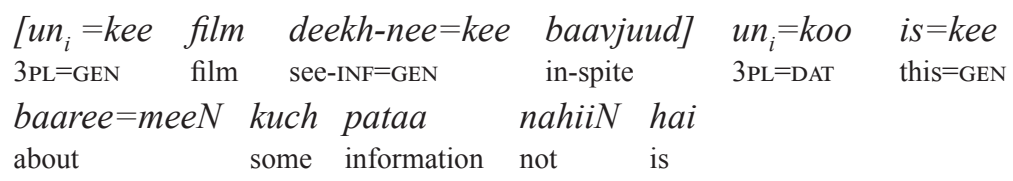

'In spite of their having seen the film ${ }_{\mathrm{i}}$, they don't know much about $\mathrm{it}_{\mathrm{i}}$.' 
PRO occurs in non-finite clauses in syntactic positions which would be assigned null/ nominative case in a finite clause. There are two consequences. Controlled PRO occurs in syntactic positions assigned structural case, nominative or genitive, but not lexical case (DAVISON 2008). The second consequence is that, since objects can be assigned unmarked nominative case (MOHANAN 1993), it must be asked whether objects correspond to controlled PRO as well.

I will deal with the first issue in connection with binaa sentences. The embedded clause PRO subject in (15) is possible if the embedded verb is dee-naa 'give-INF.' whose subject is given structural case in finite contexts (16). But it is ill-formed if the verb is mil-naa 'get, meet with', which assigns lexical case (17):

$$
\begin{aligned}
& \text { woo }_{i} \quad\left[P R O_{i}\right. \text { paisaa *mil-naaldee-naa] caah-tii hai } \\
& \text { 'She }{ }_{\mathrm{i}} \text { wants }\left[\mathrm{PRO}_{\mathrm{i}}\right. \text { to receive/give money.' } \\
& \text { want-IMPF is }
\end{aligned}
$$

woo paisaa dee deegii

3sG.NOM money-NOM give give.FUT.3sG.F

'She will give money.'

$$
\begin{aligned}
& \text { usee paisaa mil-eegaa } \\
& \text { 3sG.DAT money-Nom receive-FUT.3sG.m } \\
& \text { 'She will get money.' }
\end{aligned}
$$

There are two ways of expressing 'to like': pasand aa-naa 'liking come' and pasand kar-naa 'liking do'. The first expression assigns lexical dative case to its subject (18a, b), while the second does not (19).

$$
\begin{aligned}
& \text { maiN }=\text { nee yah kitaab }_{i} \quad \text { [binaa PRO } e_{i} \text { pasand kiyee] paRh-ii } \\
& \mathrm{I}=\mathrm{ERG} \text { this book without liking do-PF.OBL read-PF } \\
& \text { 'I read this book without liking it.' }
\end{aligned}
$$

$$
\begin{array}{llllll}
\text { maiN=nee }_{\text {yah kitaab }} \quad \text { [PRO } e_{i} & \text { na pasand } & \text { kar-tee } & \text { hu-ee] paRh-ii } \\
\text { I=ERG book } & & \text { not liking } & \text { do-IMPF } & \text { be-PF.OBL read-PF } \\
\text { 'I read this book not liking it.' } & & & &
\end{array}
$$

?? maiN=nee yah kitaab ${ }_{i} \quad\left[\right.$ binaa PRO $e_{i}$ pasand aa-ee]=bhii paRh lii $\mathrm{I}=\mathrm{ERG} \quad$ this book without liking come-PF=also read take.PF

'I read this book without even liking it.'

In binaa sentences, the lexically cased option is odd with a null subject (19), but not the structurally cased subject (18a). This contrast suggests that the binaa clause subject is a controlled PRO, subject to the same restriction on lexically cased infinitive subjects which was established above in (15)-(17).

\section{PARTICIPIAL MODIFIER CLAUSES}

I digress briefly from the discussion of binaa clauses to consider again the question of null operators in participial clauses. Interrogatives in situ always have widest scope, so that no embedded question interpretations are possible in infinitives and participial clauses 
(10c). This fact casts doubt on the A' chain analysis of parasitic gaps, as the binaa construction with a null object consists of a verb in the perfective participle form (20a):

$\begin{array}{lll}\text { (20a) } & \begin{array}{l}\text { binaa } \\ \text { without } \\ \text { 'without reading' }\end{array} & \begin{array}{l}\text { paRh-ee } \\ \text { read-PF.OBL }\end{array} \\ \text { (20b) } & \text { binaa }\left[\mathrm{CP} \mathrm{OP}_{i} L_{I P} \mathrm{PRO}_{j} e_{i} \text { paRh-ee }\right.\end{array}$

To maintain the A' chain analysis for the null object in a binaa clause, the structure would have to be as in (20b), with a null operator in Spec of CP coindexed with the null object.

There is a participial construction in Hindi/Urdu which might well be a candidate for such a structure. Perfective and imperfective participle clauses can be used as modifiers (21), with an interpretation similar to the 'predication' interpretation of a relative clause (22):

$\begin{array}{llllll}{[[a a p=k i i} & e_{i} l i k h-i i & h u-i i] & \left.\boldsymbol{k i t a a b}_{i}\right] & \text { acchii } & h a i \\ \text { you=GEN } & \text { write-PF } & \text { be-PF } & \text { book } & \text { good } & \text { is }\end{array}$

'[The book [which you wrote $\left.\left.\underline{\underline{e}}_{i}\right]\right]$ is good.'

\begin{tabular}{|c|c|c|c|c|c|}
\hline $\begin{array}{l}{[a a p=\text { nee }} \\
\text { you }=\text { ERG }\end{array}$ & $\begin{array}{l}\text { joo } \\
\text { which.REL }\end{array}$ & $\begin{array}{l}k_{\text {book }} \\
\text { itaab }\end{array}$ & $\begin{array}{l}\text { likh-ii } \\
\text { write-PF }\end{array}$ & $\begin{array}{l}\text { hai] } \\
\text { be-PF }\end{array}$ & $\begin{array}{l}w_{o o}{ }_{i} \\
3 \mathrm{SG}\end{array}$ \\
\hline
\end{tabular}

'[The book [which you wrote $\left.\underline{\underline{e}}_{\underline{i}}\right]$ ] is good.'

Does the participial clause in (21) have a null operator corresponding to the relative determiner in (22)? If so, then the null object in (21) could be considered an A'-bound variable.

On the other hand, there are interesting conditions on the null elements of participial modifier clauses. What is missing from the participial clause corresponds to the NP to which the participial clause is adjoined, as in the bold constituent of (21). Transitive perfective clauses (with a small number of exceptions) have an obligatorily null object, with an optional genitive subject (21), while intransitive perfective modifier clauses and all imperfective clauses require null subjects. No other constituents may be null and also coindexed with the matrix NP. Subjects and objects are just the constituents which receive nominative structural case in Hindi. ${ }^{5}$

An alternative view, then, is that the null constituent coindexed with the matrix NP is $\mathrm{PRO}$, and the coindexing relation is an instance of the general control relation, not a special case of A' binding by a null operator. Let us look at perfective transitive participial clauses to see whether the prohibition against control of lexically cased NPs holds in modifier clauses like those in (21).

The verb sun-naa 'hear' has a structurally cased object aawaaz 'noise, voice'(23). The verb Dar-naa 'fear', on the other hand, marks its object with the lexical case-see 'from' (24):

$$
\begin{aligned}
& \text { baccooN=nee bijlii=kii aawaaz sun-ii } \\
& \text { children=ERG thunder=GEN sound-NOM hear-PF } \\
& \text { 'The children heard the sound of thunder.' }
\end{aligned}
$$

5 See, however, Hook \& Pradeshi 2013 (this volume) for an extended discussion of the participial relative construction in Marathi, noting which constituents in a participle can be coindexed with the modified head noun. 


$\begin{array}{llll}\text { baccee } & \text { bijlii=see } & \text { Dar } & \text { gay-ee } \\ \text { children-NOM } & \text { thunder=from be.afraid } & \text { go-PF } \\ \text { 'The children became frightened of the thunder.' }\end{array}$

If we form perfective participles from these sentences, to modify NPs, then the results show a contrast:

$$
\begin{aligned}
& \text { ? [[baccooN=kii } \left.e_{i} \text { sun-ii hu-ii] } \text { aawaaz }_{i}\right] \text { teez thii } \\
& \text { children }=\text { GEN hear-PF be-PF sound loud was }
\end{aligned}
$$

'[The sound ${ }_{i}\left[\right.$ which the children heard $\left.\left.\underline{e}_{i}\right]\right]$ was loud.'

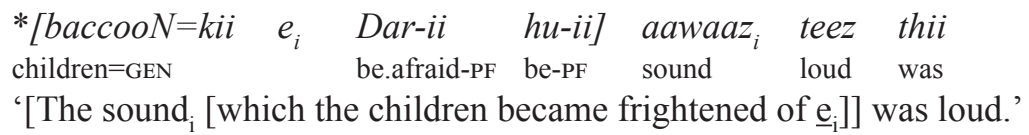

The nominative object in (23) corresponds to the null object in (25), perhaps with some pragmatic or stylistic oddity. But the lexically cased object does not correspond to the null object of (26); the sentence is ungrammatical in the intended meaning (though grammatical in the meaning 'the frightened voices/sound of the children' R. Agnihotri, p.c.).

So we see that the same restriction on subject control holds also for perfective modifier clauses with null objects. If the null object in these instances is really controlled PRO, then the construction conforms to MANZINI's insight (1983) that obligatory control is a binding relation within a well-defined syntactic domain, such as verb and complement, modifier and head. In Hindi, the control relation must be possible at "long distance" (pace MoHANAN 1983), to account for the following facts. Let us assume that there is a control relation in both (27) and (28):

$$
\text { [[baccooN=kaa PRO, kiyaa huaa] kaami bahut muSkil thaa }
$$

\begin{tabular}{|c|c|c|c|}
\hline $\begin{array}{l}\text { waalid-saahab }=\text { nee } \\
\text { father }=\mathrm{HON}=\mathrm{ERG}\end{array}$ & $\begin{array}{l}\text { hameeN }_{i} \quad{ }_{\text {we.DAT }} \\
\text { PRO }\end{array}$ & $\begin{array}{l}\text { kaam } \\
\text { work }\end{array}$ & $\begin{array}{l}\text { kar-nee] }=k o o \\
\text { do-INF=ACC }\end{array}$ \\
\hline
\end{tabular}

children $=$ GEN do.PF be-PF work very difficult was

'[The work [which the children did $\underline{\mathrm{e}}_{\mathrm{i}}$ ] was very difficult.'

It is possible to combine these two sentences and the two control relations, into one sentence (29):

$$
\begin{aligned}
& {\left[\left[\left[\text { walid }=\text { saahab }=k a a \quad h_{\text {ameeN }} \quad\left[P R O_{i} \boldsymbol{P R O}_{j} \quad k a r-n e e\right]=k o o \quad k a h \text {-aa }\right]\right.\right.} \\
& \text { father }=\mathrm{HON}=\mathrm{ERG} \quad \text { we.DAT } \quad \text { do-INF }=\mathrm{ACC} \text { say-PF } \\
& \text { kaam }_{j} \text { bahut muSkil thaa } \\
& \text { work very difficult was }
\end{aligned}
$$

'The work [which Father told us ${ }_{i}\left[\mathrm{PRO}_{\mathrm{i}}\right.$ to do $\left.\mathbf{P R O} \mathbf{O}_{\mathbf{j}}\right]$ ] was very difficult.'

(Many thanks to Master Minhajjudin, Varanasi, for this judgement.)

The coindexing of the $\mathrm{PRO}_{\mathrm{j}}$ object with kaam 'work' crosses two non-finite clause boundaries. While this fact might be held to be evidence for an unbounded A' dependency of a null operator and a variable, it is not unexpected as an anaphoric relationship in a language which has "long-distance" anaphors (GURTU 1992; DAVISON 2000). Controlled PRO, 
whether subject or object, is subject to the restriction on lexical as opposed to structural case. This discussion shows that Hindi-Urdu does have long-distance coindexing of PRO, like anaphors, but without necessarily having overt movement. These facts also support an analysis of the object gap in the binaa clause as a null pronominal rather than the gap left by A' movement. See section 7 below.

\section{PROPERTIES OF PRO}

Both PRO and pro participate in backward pronominal coindexing, as in (30)-(31):

$$
\begin{gathered}
{\left[\mathrm{PRO}_{\mathrm{i}} \text { is baat=koo sun-kar] } \begin{array}{l}
\text { bhaaii }_{i}=\text { koo } \\
\text { this matter=ACC hear-PART } \\
\text { brother-DAT }
\end{array}\right.} \\
\text { anger }
\end{gathered}
$$

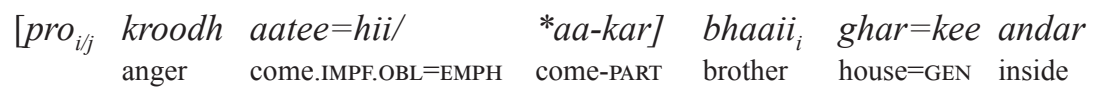

$$
\begin{aligned}
& \text { ghus gayaa } \\
& \text { enter go-PF }
\end{aligned}
$$

'[PRO getting angry] brother went into the house.'

Conjunctive participle adverbial clauses marked by the verbal suffix -kar 'having V-ed' must have null controlled PRO subjects, which, as seen above in (3), cannot have lexical case, such as the dative subject of kroodh aa-naa 'anger come' (30)-(31). The oblique imperfective participle $a a$-tee $=$ hii 'come-IMPF.OBL=only; as soon as' may have a null subject (31) or an overt subject (32)-(33), which bears the dative lexical case selected by kroodh $a a-$ 'get angry'.

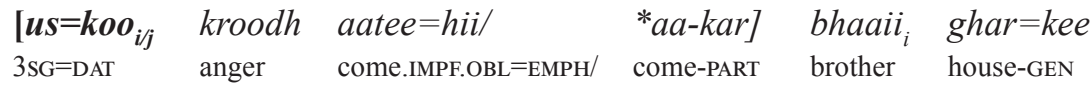

$$
\begin{aligned}
& \text { andar ghus ga-yaa } \\
& \text { inside enter go-PF } \\
& \text { '[As soon as he } \mathrm{i}_{\mathrm{i} j \mathrm{j}} \text { got angry] brother }{ }_{\mathrm{i}} \text { went into the house.' }
\end{aligned}
$$

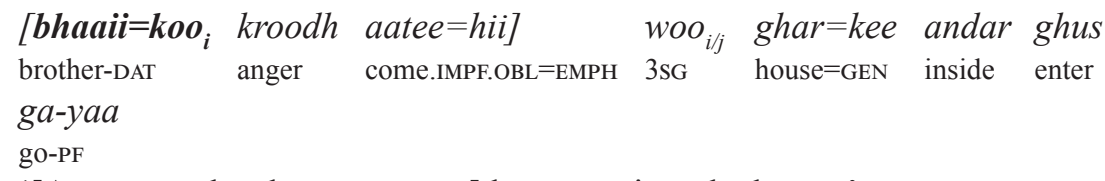

From the contrast of subjects in -kar and V-tee hii adverbials, we conclude that PRO subjects are found in only the first type, and the oblique participle has a pro subject, which may alternate with overt subjects. 


\section{THE NULL OBJECT IN THE binaa CONSTRUCTION}

Returning to the question of null objects in binaa sentences, we now need to know whether these null objects can correspond to lexically cased as well as structurally cased NPs, and whether the empty category is optional or obligatory. The sentence in (34) shows that the null category is optional, and it does correspond to a lexically cased object (35):

$$
\begin{aligned}
& \text { maiN=nee apnii saheelii=koo [binaa (us=see) mil-ee }] \quad k a l \\
& \text { I=ERG self's friend }=A C C \text { without } 3 \mathrm{sG}=\text { with meet-PF.OBL yesterday } \\
& \text { deekh-aa. } \\
& \text { see-PF } \\
& \text { 'I saw my friend yesterday [without meeting (her)].' } \\
& \begin{array}{llll}
\text { maiN apnii } & \text { saheelii=see } & \text { mil-ii/mil ga-ii } \\
\text { I } & \text { self's } & \text { friend=with } & \text { meet-PF/meet go-PF } \\
\text { 'I met my friend.' } &
\end{array}
\end{aligned}
$$$$
u_{i}=\text { nee } \text { apnee }_{i} \quad \text { pitaa }_{j}=\text { see } \quad \text { [binaa } e_{i} \text { aaNkh milaa-ee] baat kii }
$$$$
3 \mathrm{~s}=\text { ERG self's father-with without eye mix-PF matter do-PF }
$$$$
\text { 'He talked to his father without meeting his eye/looking at him.' }
$$

$\begin{array}{lllll}u s=n e e & \text { pitaa }=\text { see } & \text { aaNkh } & \text { nahiiN } & \text { milaa-ii } \\ 3 \mathrm{~s}=\mathrm{ERG} & \text { father=with } & \text { eye } & \text { not } & \text { mix-PF }\end{array}$

'He did not meet his father's eye/did not look at his father.'

The pair of sentences in (36) and (37) establishes the same point as (35) and (36).

The null object may be in an embedded (non-finite) clause:

$$
\begin{aligned}
& \text { maiN }_{i}=\text { nee } \text { yah kitaab [binaa }\left[P R O_{i}\left[\operatorname{PRO}_{i} \text { e } \quad \text { paRh-naa }\right]\right. \text { caah-tee } \\
& \text { I=ERG this book without read-INF want-IMP } \\
& \text { hu-ee] khariid lii } \\
& \text { be-PF buy take-PF } \\
& \text { 'I bought this book without [PRO wanting [PRO to read it]].' }
\end{aligned}
$$

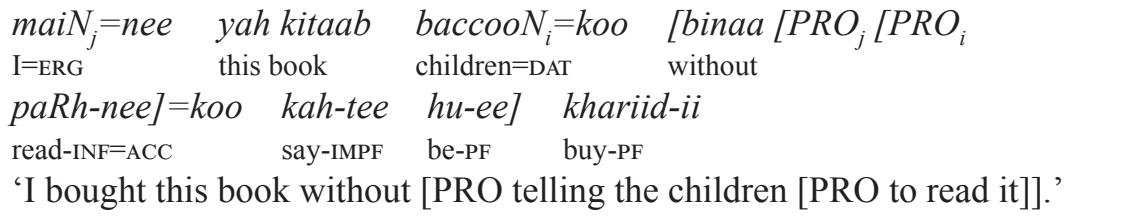

We see that the null object behaves like a pronominal, because to get a bound-variable interpretation from an operator antecedent, it must be c-commanded by the operator kaun-sii in (39a) rather than the reverse (39b):

$\begin{array}{llllll}\begin{array}{l}\text { aap }=\text { nee } \\ \text { you=ERG }\end{array} & \begin{array}{l}\text { kaun-sii kitaab } \\ \text { which-like book }\end{array} & \text { [binaa PRO e } & \text { khariid-ee] } & \text { paRh } & \text { lii? } \\ \text { without } & \text { buy- PF } & \text { read } & \text { take.PF }\end{array}$

'Which book did you read without buying?'

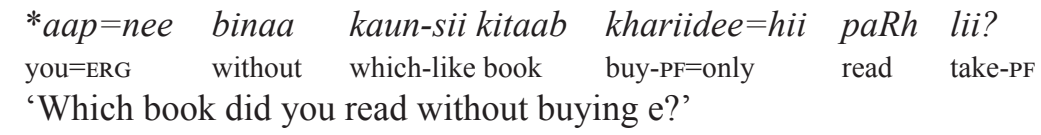




\section{WHAT KIND OF SUBJECT IS POSSIBLE IN THE binaa CLAUSE?}

I have proposed above that the binaa participle has a PRO transitive subject and a pro transitive object. A question which arises has to do with intransitive verbs of the UNACCUSATIVE type, in which the subject originates in object position, and moves to subject position for case and the requirement that every clause should have a subject (Extended Projection Principle). Unaccusative verbs include verbs in Hindi-Urdu such as pahuNc-naa 'arrive', and gir-naa 'fall'.

Bina participles which these verbs would have the same pronominal in both the subject and the object position:

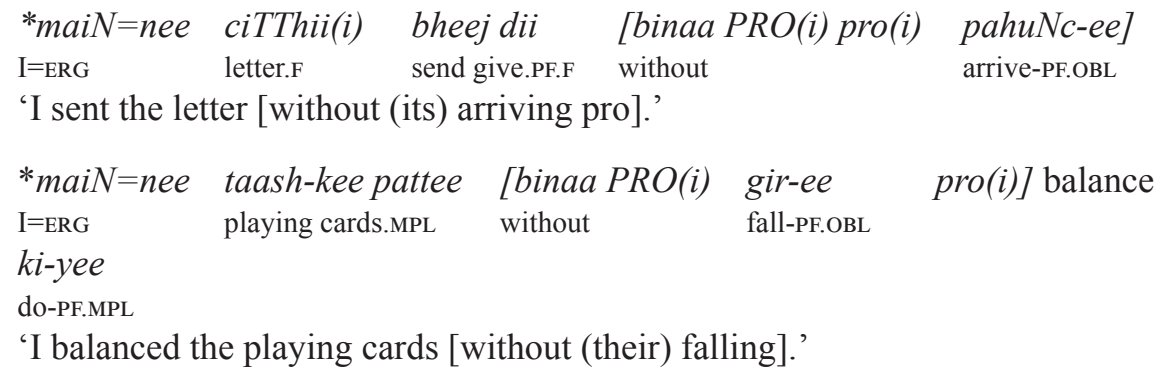

Rajesh Bhatt (p.c) finds that these sentences are ungrammatical in the intended meaning; but they are well-formed with the meaning 'I sent the letter [without (myself) arriving]', 'I balanced the cards without (myself) falling over.' We can conclude from these judgements that it is required to have a PRO subject of the binaa participle, and this PRO must be controlled by the subject of the main clause. These sentences show that while it would be possible to have an intransitive verb in the participle, the unaccusative object-promoted-tosubject is inaccessible. The pro object of the participle is also just an option, as we saw in (34) above, in which an overt object is also possible.

\section{BUT CAN THERE BE SOME PARASITIC GAPS IN HINDI-URDU? A RESPONSE TO MANETTA 2013}

The normal unmarked form of questions in Hindi-Urdu does not require movement to the left periphery of the clause, as it does in English. There may be some clause-internal movement to a focus position associated with vP: Compare (42a) with (42b).

$$
\begin{aligned}
& \text { us=nee kitaab=koo paRh-aa } \\
& 3 \mathrm{SG}=\mathrm{ERG} \text { book=ACC read-PF } \\
& \text { 'He/She read the book.' }
\end{aligned}
$$

$$
\begin{aligned}
& \text { kitaab=koo kis=nee } \\
& \text { book=ACC who=ERG } \\
& \text { 'Who read the book?' }
\end{aligned}
$$

But is it not usual, though possible, to have the question phrase placed all the way to the left; many examples are given in MaHAJAN 1990. Speakers disagree about them and it has been hard to determine exactly what kind of syntactic or discourse factors favor this 
kind of displacement to the left. Nevertheless they are acceptable under some circumstances.

ManetTA (2013) basically accepts the arguments for a pro object in most cases. She proposes, however, that A' gaps also exist in Hindi-Urdu, as in other apparently wh- in situ languages cited in MANETTA 2013. This means that Hindi-Urdu has two means of creating object gaps. One uses the null pronominal, the other a genuine gap created by movement. The test for the movement gap is whether it allows "reconstruction". This term means that the moved phrase exists in two places, the leftward position to which it is moved, and the original position in which it may serve as a local antecedent for a reflexive pronoun:

[Which picture of himself $]_{j}$ did Mary say [that John $_{i /}$ liked $\left.e_{k}\right]$ ?

The moved phrase with the reflexive pronoun himself must also be in the object position of liked in order to be locally bound by the subject antecedent John.

MunN (1994) offers the following sentence in (44) as an example of reconstruction into the position of a parasitic gap:

$$
\text { [Which picture of himself } \left.]_{j} \text { did [every boy } y_{i} \text { who saw e] say [Mary liked } t_{j}\right] \text { ? }
$$

The wh- phrase containing a locally bound reflexive pronoun must reconstruct to the position of $\boldsymbol{e}$, the parasitic gap position. Otherwise the antecedent every boy would not locally c-command the reflexive pronoun in which picture of himself. If the wh-phrase was reconstructed to the position $t_{j}$ in [Mary liked $t_{j}$, the local antecedent in the subordinate clause would not match for index or gender features and would be wrongly coindexed.

On the assumption that (44) has a well-formed counterpart in Hindi-Urdu, there would be reconstruction into an empty category which would behave like a parasitic gap, rather than a null pronominal (45).

$$
\begin{aligned}
& \text { [kaun-sii apnii }{\text { tasviir }=k o o]_{j}}_{\text {har laRkee }}{ }_{i}=\text { nee } \quad \text { [binaa } P R O_{i} \boldsymbol{e}_{j} \text { deekh-ee] } \\
& \text { which-like self's picture }=\mathrm{ACC} \text { every boy }=\mathrm{ERG} \text { without see-PF.OBL } \\
& \text { kah-aa [ki miriam=nee } t_{j} \text { pasand ki-yaa]? } \\
& \text { say-PF that Miriam=ERG liking do-PF }
\end{aligned}
$$

'Which picture of himself ${ }_{i}$ did each boy ${ }_{i}\left[\right.$ without $\mathrm{PRO}_{\mathrm{i}}$ seeing $\boldsymbol{e}_{j}$ ] say that Miriam liked $t_{j}$ ?'

The reflexive pronoun apnii must be coindexed with a local antecedent in the binaa clause, which is the controlled subject PRO. It cannot be coindexed with miriam, which is in an entirely different clause, the finite complement of 'say'. If the sentence (45) is generally acceptable, then there is some evidence that under special circumstances, Hindi-Urdu can have gaps of the parasitic type, as well as the universally available null pronominals in the binaa construction. These null pronominals are found in both questions and statements.

There needs to be further exploration of sentences like (45). They need to be tested by a range of speakers, and they need to have non-question counterparts, with scrambling, focus or topicalization, to see if the sentence is still possible with the intended reading. If such sentences are possible, though not the norm, then MANETTA (2013) has shown that Hindi-Urdu is able to form a coindexed gap construction in two possible ways, with a null 
pronominal as the default, and movement leaving a parasitic gap as a possibility. This leaves open the still surprising idea that languages allow more than one set of principles to form a grammatical structure in one and the same language. It was widely assumed in the Chomskyan tradition (such as CHOMSKY 1981) that Universal Grammar consists of a finite repertory of grammatical principles, which could be implemented in slightly differing ways according to parameter values chosen by a given language. This assumption has recently been called into question with respect to a number of languages. ${ }^{6}$

\section{CONCLUSION}

The participial construction headed by binaa 'without' offers an opportunity to explore the properties of null categories in Hindi/Urdu and the factors which constrain them. As these factors differ, it is possible to narrow down the type of empty category found in the subject and object positions of the oblique perfective participle clause headed by binaa. The subject position is likely to be PRO, identified by the restriction against lexically cased controlled PRO. The object position is not constrained by this condition, leaving pro and a wh- variable as possibilities. The wh- variable or parasitic gap hypothesis is undermined by the absence of obligatory A' movement, and by the fact that operators typically do not have narrow scope over non-finite clauses in Hindi/Urdu, unlike English. While we might propose a null operator in the Spec of a participial modifier clause, the properties of these modifier clauses make the null element more likely to be controlled PRO, subject to the lexical case restriction. While binaa sentences might appear to be analogous to English parasitic gap clauses, in fact on closer examination, another kind of empty category is present. Nevertheless, the arguments in MANETTA 2013 suggest that for at least some speakers, Hindi-Urdu may be able exceptionally to construct parasitic gaps, opening up interesting questions about how a language can have multiple ways of forming structures, with the still unanswered question of how the language learner learns to select the right method of syntactic construction.

\section{ACKNOWLEDGEMENTS}

An earlier version of this paper was presented at the Conference on Nulls, Delhi University, 1999. I wish to thank the audience for grammaticality judgments and helpful suggestions, as well as those directly cited in the paper, including Rajesh Bhatt. Thanks also to Emily Manetta for raising intriguing objections to my earlier conclusion and for stimulating me to return to the 'without' construction and its properties. Thanks to Liudmila V. Khokhlova and Hans Henrich Hock for including this paper in the current volume.

As always, I am grateful to A. Azar, Y. Romero, S. Cassivi, D.J. Berg, M. Yao, A Comellas, and T. Gross.

6 See Manetta 2013 for examples, as well as Davison 2013, which discusses different versions of control (coindexed null subjects in South Asian languages). 


\section{REFERENCES}

Chomsкy Noam. 1981. Lectures on Government and Binding. Dordrecht: Kluwer Publishing Company.

CHомsкy Noam. 1982. Some Concepts and Consequences of Government and Binding. Cambridge: MIT Press.

Сномsкy Noam. 1986. Barriers. Cambridge: MIT Press.

Chomsky Noam. 1995. The Minimalist Program. Cambridge: MIT Press.

DAvison Alice. 2000. "Lexical Anaphors and Pronouns in Hindi/Urdu." In: Lust et al. 2000: 397-470.

DAvison Alice. 2008. "A Case Restriction on Control: Implications for Movement." Journal of South Asian Linguistics 1(1), 29-54. Tiger.sprachwiss.uni-konstanz.de/ jsal/ojs/index.

DAvison Alice. 2013. "Varieties of Control in South Asian Languages: A Paradoxical Situation for UG." Paper presented at Formal Approaches to South Asian Languages, USC, March 2013.

ENGDAHL Elisabet. 1983. "Parasitic Gaps." Linguistics and Philosophy 6, 5-34.

GurTu Madhu. 1992. Anaphoric Relation in Hindi. Delhi: Munshiram Manoharlal.

Hook Peter, Pardeshi Prashant. 2013. "Prenominal Noun Modifying Constructions in Marathi and the Noun Phrase Accessibility Hierarchy." Lingua Posnaniensis 55(2), 77-89 (this volume).

Huang C.T. James. 1984. "On the Distribution and Reference of Empty Pronouns." Linguistic Inquiry 15, 531574.

Lust Barbara C., Wali Kashi, Gair James W., Subbarao K.V. (eds.). 2000. Lexical Anaphors and Pronouns in Selected South Asian Languages: A Principled Typology. Berlin-New York: Mouton de Gruyter.

Mahajan Anoop. 1990. The A/A-Bar Distinction and Movement Theory. MIT PhD dissertation.

ManetTa Emily. 2010. "Wh Expletives in Hindi-Urdu: The vP Phase." Linguistic Inquiry 41(1), 1-34.

Manetta Emily. 2013. "Signs of Movement: Parasitic Gaps in Hindi-Urdu." Paper presented at Formal Approaches to South Asian Languages, USC, March 2013.

Manzini Rita. 1983. "Control and Control Theory." Linguistic Inquiry 14(3), 421-446.

Mohanan K.P. 1983. "Functional and Anaphoric Control.” Linguistic Inquiry 14(4), 641-674.

Mohanan Tara. 1993. "Case Alternations on Objects in Hindi." South Asian Language Review 3(1), 1-30.

MunN Alan. 1994. "A Minimalist Account of Reconstruction Asymmetries.” Proceedings of the North East Linguistics Society 24, 397-410.

NunEs Jairo. 2004. Linearization of Chains and Sidewards Movement. Cambridge: MIT Press.

Rizzi Luigi. 1990. Relativized Minimality. Cambridge: MIT Press.

Webelhuth Gert. 1989. Syntactic Saturation Phenomena and the Modern Germanic Languages. University of Massachusetts $\mathrm{PhD}$ dissertation.

Webelhuth Gert. 1992. Principles and Parameters of Syntactic Saturation. Oxford: Oxford University Press. 